\title{
Factors related to self-care activities of patients with type 2 diabetes mellitus
}

\author{
Fatores relacionados às atividades de autocuidado de pacientes com diabetes mellitus tipo 2 \\ Factores relacionados con las actividades de autocuidado de pacientes con diabetes mellitus tipo 2
}

\begin{abstract}
Letícia Palota $\operatorname{Eid}^{1}(10$
Sílvia Aparecida Dourado Leopoldino²

Graziella Allana Serra Alves de Oliveira

Oller $^{3}$

Daniele Alcalá Pompeo²

Marlene Andrade Martins ${ }^{1}$

Laís Palota Balderrama Gueroni ${ }^{3}$
\end{abstract}

\begin{abstract}
1. Universidade Federal de Jataí.
Jataí, GO, Brasil.

2. Faculdade Regional de Medicina

de São José do Rio Preto.

São José do Rio Preto, SP, Brasil.

3. Universidade Paulista.

São José do Rio Preto, SP, Brasil.
\end{abstract}

Corresponding author:

Letícia Palota Eid.

E-mail: Ipalota@usp.br

Submitted on $02 / 16 / 2018$.

Accepted on 05/30/2018.

DOI: 10.1590/2177-9465-EAN-2018-0046

\section{Abstract}

Objective: To verify self-care activities of patients with type 2 diabetes mellitus and to analyze the relationship with sociodemographic and clinical variables. Method: A cross-sectional study was performed of 149 people using the Diabetes Self-Care Activities Questionnaire. Results: Of the 15 self-care activities analyzed, appropriate behavior was observed for aspects related to medication use and inadequate for fruit/vegetable consumption, blood sugar testing and physical exercise. The correct use of medications was correlated to marital status. Regarding inadequate behaviors, there were associations of fruit/vegetable consumption with skin color and place of residence and blood sugar testing with marital status and inverse correlations of physical exercise with systolic blood pressure, pulse pressure, waist circumference and postprandial glycemia. Conclusion: The results of this research contribute by strengthening the line of care in chronic diseases and assist in divulging the importance of supported self-care. Implications for practice: The findings of this research provided information relevant to the planning of care.

Keywords: Diabetes Mellitus; Self Care; Nursing Care.

\section{Resumo}

Objetivo: Verificar atividades de autocuidado de pacientes com diabetes mellitus tipo 2 e analisar sua relação com variáveis sociodemográficas e clínicas. Método: Estudo transversal, com 149 pessoas. Utilizou-se o Questionário de Atividades de Autocuidado com Diabetes. Resultados: Das 15 atividades de autocuidado analisadas, observou-se comportamento adequado naquelas relacionadas ao uso de medicamentos e inadequado para consumo de frutas/vegetais, monitorização glicêmica e atividade física. $\mathrm{O}$ uso de medicamentos relacionou-se com situação conjugal. No tocante aos comportamentos inadequados, observou-se relação entre consumo de frutas/vegetais e cor da pele e residência; monitorização da glicemia com situação conjugal e correlação inversa entre atividade física e pressão arterial sistólica, pressão de pulso, circunferência abdominal e glicemia pós-prandial. Conclusão: Os resultados desta investigação contribuem para fortalecer a linha de cuidado em doenças crônicas e auxiliam na ênfase ao autocuidado apoiado. Implicações para a prática: Os achados desta investigação propiciaram informações relevantes para o planejamento da assistência.

Palavras-chave: Diabetes mellitus; Autocuidado; Cuidados de Enfermagem.

\section{REsumen}

Objetivo: Verificar actividades de autocuidado de pacientes con diabetes mellitus tipo 2 y analizar su relación con variables sociodemográficas y clínicas. Método: Estudio transversal, con 149 personas. Se utilizó el Cuestionario de Actividades de Autocuidado con Diabetes. Resultados: De las 15 actividades de autocuidado analizadas, se observó comportamiento adecuado a las relacionadas con el uso de medicamentos e inadecuado para el consumo de frutas/vegetales, monitorización glucémica y actividad física. El uso de medicamentos se relacionó con la situación conyugal. Con respecto a los comportamientos inadecuados, se observó relación entre consumo de frutas/vegetales con el color de la piel y residencia; la monitorización de la glucemia con la situación conyugal y la correlación inversa entre actividad física y presión arterial sistólica, presión de pulso, circunferencia abdominal y glucemia postprandial. Conclusión: Los resultados de esta investigación contribuyen para fortalecer la línea de cuidado en enfermedades crónicas y auxilian a enfatizar el autocuidado apoyado. Implicaciones para la práctica: Los hallazgos de esta investigación suministran informaciones relevantes para la planificación de la asistencia.

Palabras clave: Diabetes Mellitus; Autocuidado; Atención de Enfermería. 


\section{INTRODUCTION}

Diabetes mellitus (DM) can be defined as a heterogeneous group of metabolic imbalances, whose common denominator is hyperglycemia with possible outcomes being mainly associated with important and progressive macrovascular and microvascular structural changes; one of the chief conductive pathways is major and fatal cardiovascular events. ${ }^{1}$

Today DM is considered one of the main modifiable risk factors for heart disease, acting independently or associated with other factors, such as with hypertension, dyslipidemias and obesity, ${ }^{1}$ all of which must be the subject of joint prevention measures of the government, society, the individual and family.

The transfer of responsibility for the control of chronic diseases to the individual and family refers to terms that translate in the active role that these actors should play in order to achieve positive results, including "adherence" and "self-care."2,3

Self-care in the management of diabetes mellitus includes adherence to healthy eating, physical activity, periodic blood sugar testing, the correct intake of prescribed medications, proper foot care, and the ability to resolve conflicts and deal positively with the presence of a chronic pathological condition. ${ }^{4}$

Nationa $\left.\right|^{5-7}$ and international studies ${ }^{8,9}$ have sought to study this behavior and correlate it to clinical and socioeconomic variables. However, the results are heterogeneous reflecting the need to conduct research on the issue in different social and clinical contexts.

A solid evidence base demonstrates that adherence to adequate self-care in diabetes potentiates and facilitates therapeutic success, mediating satisfactory outcomes such as improved metabolic control, ${ }^{10}$ quality of life,${ }^{11}$ and anxious and depressive symptoms, ${ }^{11}$ and the reduction of cardiovascular risk. ${ }^{12}$ Thus adherence, as a cornerstone in the management of the disease, needs to be studied and promoted in the setting of the social, demographic and clinical differences of each population.

It is necessary to increase the identification of levels of adherence to self-care activities and the factors that influence the adopted behavior. This diagnosis will support assertive interventions, and positively influence the metabolic parameters of the diabetic individual and, consequently, the morbidity and mortality profiles.

In view of the above, the objective of this study was to investigate the self-care activities of patients with type $2 \mathrm{DM}$ in an outpatient setting and to correlate sociodemographic and clinical variables to self-care activities.

\section{METHOD}

This cross-sectional quantitative study was developed at a government clinic in a provincial city of the state of São Paulo. Several activities are provided by the multiprofessional team of this clinic for people with hypertension and DM, including the organization of Chronic Health and Adult Food Education Groups.

The study population was constituted by male and female over 18-year-old patients with a diagnosis of type 2 DM for at least six months who were under drug treatment using insulin and/or oral antidiabetic agents and followed-up at this health clinic. The exclusion criteria were the presence of advanced complications, not being able to communicate verbally and not having cognitive conditions that allowed their participation in the study. The latter variable was assessed by the participants ability to inform their age or date of birth, residential address, day of week and month. ${ }^{6}$ Advanced-stage complications included hemodialysis, amaurosis, incapacitating sequelae of stroke/ heart failure, amputations and active ulcers of the lower limbs, and the use of a wheelchair or gurney. ${ }^{6}$

Participants who met the inclusion criteria were selected by means of consecutive and non-probabilistic sampling $(n=149)$ with data collection being performed from $1 / 9 / 2016$ to $4 / 5 / 2017$.

Sociodemographic and clinical data were collected by means of an instrument created by the researchers themselves that investigated the following variables: sex, skin color, place of residence, schooling, marital status, income, occupation, age, weight, height, body mass index (BMI), abdominal circumference, systolic blood pressure (SBP), diastolic blood pressure (DBP), pulse pressure (PP), presence of comorbidities and variables related to $\mathrm{DM}$. The variables related to $\mathrm{DM}$ included duration of diagnosis, duration of diabetic therapy, daily frequency of applications of insulin and oral antidiabetic agents, presence of acute complications (diabetic ketoacidosis, hyperglycemic hyperosmolar state, hypoglycemia) and the presence of chronic complications (nephropathy, retinopathy, macrovascular diseases, neuropathy). The laboratorial variables, such as fasting and postprandial blood glocose levels, were collected from the patient's health records considering the previous 12 months.

Prior to data collection, the two interviewers underwent four hours of training to standardize the procedures involved in this stage. Patients who met the inclusion criteria were invited to participate in the study. After they agreed, the data collection instruments were applied in the form of an interview that lasted approximately 30 minutes inside the outpatient clinic itself. 
An aneroid sphygmomanometer with correct regulation and calibration was used to measure and interpret blood pressure levels following the recommendations of the guidelines of the Brazilian Society of Cardiology. ${ }^{13}$ Analog weighing scales with an anthropometric ruler was used to measure weight and height. Abdominal circumference was assessed using a 150-centimeter long inelastic tape measure.

The guidelines of the Brazilian Association for the Study of Obesity and Metabolic Syndrome were adopted as the cutoff point for abdominal circumference and body mass index, ${ }^{14}$ which states that the abdominal circumference is altered when the values are $\geq 94 \mathrm{~cm}$ for men and $\geq 80$ for women. The BMI was calculated and categorized as underweight $\left(<18.5 \mathrm{~kg} / \mathrm{m}^{2}\right)$, eutrophic (from 18.5-24.9 kg/m²), overweight (from 25.0-29.9 $\mathrm{kg} / \mathrm{m}^{2}$ ), Class I obesity (from $30.0-34.9 \mathrm{~kg} / \mathrm{m}^{2}$ ), Class II obesity (from $35-39.9 \mathrm{~kg} / \mathrm{m}^{2}$ ) and Class III obesity $\left(>40 \mathrm{~kg} / \mathrm{m}^{2}\right) .^{14}$

Self-care activities were assessed using the Diabetes SelfCare Activities Questionnaire (DAQ), the translated version of the Summary of the Diabetes Self-Care Activities Questionnaire $($ SDSCA $){ }^{15}$ from the original in English, ${ }^{16}$ which was then adapted and validated for use in Brazil with good internal consistency and an inter-item correlation of 0.86 as measured by Cronbach's alpha.

The DAQ is a specific self-administered instrument used to assess self-care activities of diabetics. It has 15 assessment items distributed in seven domains: "general diet" (two items), "specific diet" (three items) "physical exercise" (two items), "blood sugar testing" (two items), "foot care" (three items) and "medication use" (three items dependent on the drug regimen). It also includes an evaluation of smoking that is considered separately because it is coded differently, with emphasis on the average number of cigarettes consumed per day. ${ }^{6,15}$

This instrument evaluates the performance of a given behavior on days per week, so the scores of each item can vary from zero to seven, with higher scores indicating better results. ${ }^{11}$ The values were inverted for the items of the specific feeding domain, (e.g. $7=0,6=1,5=2,4=3,3=4,2=5,1=6,0=7$ ) as recommended in the revised DAQ. ${ }^{16}$ Subjects were classified as smokers or nonsmokers and the proportion of smokers was considered for the analysis of this variable. ${ }^{6,15}$

It is noteworthy that the domains "general feeding", "physical exercise" and "blood sugar testing" have good correlations and, therefore, they were evaluated as a total mean score. The other domains of the DAQ were evaluated item by item, due to the weak correlation between them. ${ }^{15}$

For this study, a self-care behavior was considered desirable when the mean obtained was greater than four. The choice of this cut-off is justified because it corresponds to the most desirable self-care activities. This cut-off point was also adopted for items whose scores were reversed, relating to the number of days of the week during which the self-care activity was performed. ${ }^{6}$
The results were analyzed using the Statistical Package for the Social Sciences (SPSS) software, version 23.0. The Kolmogorov-Smirnov normality test for quantitative variables was initially applied. Quantitative variables, including age and items of self-care activities, are presented as means \pm standard deviation (SD) and qualitative or categorical variables are described as absolute and relative frequencies.

Correlation analysis was also performed using the Spearman coefficient to compare numerical variables. The Mann-Whitney and the Kruskal-Wallis tests were used to compare two and three groups, respectively of numerical variables having a non-normal distribution with categorical and with ordinal scale variables; ANOVA was used to analyze the variables that presented statistical significance. In all analyses, a $p$-value $<0.05$ was considered statistically significant.

This study was approved by the Research Ethics Committee of the Medical School in São José do Rio Preto (\#1.443.522, on March 9, 2016)

\section{RESULTS}

Of the 149 patients with type $2 \mathrm{DM}, 96$ (64.4\%) were female and the mean age was $61.25 \pm 10.90$ years. The majority stated they were white $(n=79 ; 53.0 \%)$, living in urban areas $(n=143$; $96.0 \%)$, having a partner $(n=100 ; 67.1 \%)$, with an income of two or less minimum wages ( $n=134 ; 89.9 \%$ ), had up to nine years of schooling $(n=120,80.5 \%)$, and were retired $(n=57,38.3 \%)$ or wage earners $(n=57 ; 38.3 \%)$.

Regarding clinical data, 85 (57.7\%) patients had blood pressure values classified as hypertensive and 19 (12.7\%) were prehypertensive. The mean BMI was $30.4 \mathrm{~kg} / \mathrm{m}^{2}$, with the majority classified as obese ( $n=70 ; 46.9 \%)$, followed by overweight $(\mathrm{n}=51 ; 34.2 \%)$. The mean abdominal circumference was 106 $\mathrm{cm}$, with this variable being elevated in $129(86.5 \%)$ subjects. Only 46 participants of the sample had a record of their fasting blood sugar levels for the previous year recorded in their charts, with an average of $174.82 \mathrm{mg} / \mathrm{dL}$. Postprandial blood glucose values were found in 104 charts, with a mean of $203.19 \mathrm{mg} / \mathrm{dL}$.

The most commonly reported comorbidity was systemic arterial hypertension ( $\mathrm{n}=105 ; 70.4 \%$ ), followed by dyslipidemia $(n=24 ; 16.1 \%)$. The mean time from diagnosis was $10.2 \pm 7.98$ years. Among the drugs used to control diabetes, the majority of cases reported taking oral antidiabetic medications $(n=143$ $95.9 \%) ; 74(51.7 \%)$ reported taking this medication in isolation and $69(48 ; 2 \%)$ as an association of two or more drugs. In addition, the majority reported taking oral antidiabetic medications more than once a day $(n=122 ; 85.3 \%)$ with an average of 2.3 times a day. The mean time of use was 9.4 years. Thirty-eight (25.5\%) patients reported taking insulin over a mean time of 7.2 years; the daily application rate was, on average, twice a day. As to smoking, 81 (54.3\%) people reported never having smoked 
with the average cigarette consumption of the smokers $(n=21$; $14.0 \%$ ) being 1.95 cigarettes daily.

Table 1 shows the average score for self-care activities in days per week.

Table 2 and 3 show that there were significant relationships of skin color and place of residence with the consumption of fruits and vegetables; income with general diet; marital status with blood sugar testing; schooling and marital status with foot care; and marital status with taking the indicated number of pills.

Tables 4 and 5 show a correlation of fasting blood glucose with general diet; postprandial blood glucose with fruit and vegetable intake; postprandial blood glucose, SBP, abdominal circumference and PP with physical activity; age with checking the feet; and blood sugar testing with duration of insulin therapy.

\section{DISCUSSION}

In the present study, the scores relating to the self-care activities are in agreement with data from a recent national survey that showed a predominance of favorable behavior regarding medication use, ingestion of sweets and drying between the toes, and a predominance of non-favorable behavior regarding physical exercise and blood sugar testing. ${ }^{5}$

Another Brazilian study, which used the same questionnaire, reported similar findings in respect to self-care activities as in this study. However, the patients investigated reported high fruit consumption and undesirable behavior in relation to foot care different from the data reported herein. ${ }^{6}$

A third Brazilian survey conducted with 331 people with type $2 \mathrm{DM}$ showed satisfactory drug use and unsatisfactory behaviors related to blood sugar testing. However, diverging from our

Table 1. Evaluation of the items of the Diabetes Self-Care Activities Questionnaire (DAQ). São José do Rio Preto, SP, Brazil, 2017.

\begin{tabular}{|c|c|c|c|c|c|}
\hline \multirow{3}{*}{ Item } & \multicolumn{4}{|c|}{ Frequency (days of week) } & \multirow{3}{*}{ Mean* (SD) } \\
\hline & \multicolumn{2}{|c|}{$0-4$ days } & \multicolumn{2}{|c|}{ 5-7 days } & \\
\hline & $\mathbf{n}$ & $\%$ & $\mathbf{n}$ & $\%$ & \\
\hline \multicolumn{6}{|l|}{ 1. General diet } \\
\hline 1.1 Followed a healthy diet & 48 & 32.2 & 101 & 67.8 & $5.0(2.2)$ \\
\hline 1.2 Followed diet guidance given by a professional & 49 & 32.8 & 100 & 67.2 & $4.9(2.2)$ \\
\hline \multicolumn{6}{|l|}{ 2. Specific diet } \\
\hline 2.1 Ingested five or more servings of fruits and/or vegetables & 127 & 85.2 & 22 & 14.8 & $1.3(2.4)$ \\
\hline 2.2. Ate red meat and/or whole milk products & 98 & 65.7 & 51 & 34.3 & $2.8(2.4)$ \\
\hline 2.3. Ate sweets & 22 & 14.7 & 127 & 85.3 & $5.5(1.8)$ \\
\hline \multicolumn{6}{|l|}{ 3. Physical exercise } \\
\hline 3.1 Performed physical exercise for at least 30 minutes & 123 & 82.5 & 26 & 17.5 & $1.6(2.5)$ \\
\hline 3.2 Performed specific physical exercise (swimming, walking, etc.) & 125 & 83.8 & 24 & 16.2 & $1.5(2.4)$ \\
\hline \multicolumn{6}{|l|}{ 4. Blood sugar testing } \\
\hline 4.1. Evaluated blood sugar & 127 & 85.2 & 22 & 14.8 & $1.3(2.4)$ \\
\hline 4.2. Tested blood sugar the recommended number of times & 127 & 85.2 & 22 & 14.8 & $1.3(2.4)$ \\
\hline \multicolumn{6}{|l|}{ 5. Foot care } \\
\hline 5.1. Checked the feet & 35 & 23.4 & 114 & 76.6 & $5.5(2.7)$ \\
\hline 5.2. Inspected the inside of the shoes before putting them on & 38 & 25.5 & 111 & 74.5 & $5.3(2.8)$ \\
\hline 5.3. Dried between the toes after washing them & 19 & 12.7 & 130 & 87.3 & $6.1(2.0)$ \\
\hline \multicolumn{6}{|l|}{ 6. Medications } \\
\hline 6.1 Took medicines as recommended & 5 & 3.3 & 144 & 96.7 & $6.7(2.1)$ \\
\hline 6.2. Took insulin injections as recommended & 0 & 0 & 38 & 100 & $6.9(0.3)$ \\
\hline 6.3. Took the indicated number of diabetes pills & 10 & 6.8 & 139 & 93.2 & $6.5(1.6)$ \\
\hline
\end{tabular}

\footnotetext{
* Average in days per week for self-care activities; SD: Standard deviation.
} 
Table 2. Analysis of associations of nominal sociodemographic variables with self-care activities of the DAQ. São José do Rio Preto, SP, Brazil, 2017.

\begin{tabular}{|c|c|c|c|c|c|c|}
\hline \multirow{2}{*}{$\begin{array}{l}\text { Item } \\
\text { Variable }\end{array}$} & \multicolumn{2}{|c|}{ General diet } & \multicolumn{2}{|c|}{ Fruits or vegetables } & \multicolumn{2}{|c|}{ Blood sugar testing } \\
\hline & Mean (SD) & $\mathrm{p}^{*}$ & Mean (SD) & p* & Mean (SD) & p* $^{*}$ \\
\hline Sex & & 0.76 & & 0.15 & & 0.29 \\
\hline Male & $5.0(2.3)$ & & $1.6(2.5)$ & & $1.4(2.4)$ & \\
\hline Female & $5.0(2.1)$ & & $0.9(2.0)$ & & $1.2(2.4)$ & \\
\hline Skin color & & 0.96 & & 0.00 & & 0.34 \\
\hline White & $4.9(2.2)$ & & $1.8(2.6)$ & & $1.0(2.1)$ & \\
\hline Non-white & $5.0(2.1)$ & & $0.8(2.0)$ & & $1.6(2.7)$ & \\
\hline Residence & & 0.47 & & 0.00 & & 0.66 \\
\hline Urban & $5.0(2.2)$ & & $1.2(2.3)$ & & $1.3(2.4)$ & \\
\hline Rural & $5.3(2.8)$ & & $3.5(1.8)$ & & $1.5(2.7)$ & \\
\hline Schooling & & 0.07 & & 0.23 & & 0.37 \\
\hline Illiterate & $3.8(3.1)$ & & $2.1(2.8)$ & & $0.8(1.7)$ & \\
\hline Up to 9 years & $5.2(2.0)$ & & $1.3(2.3)$ & & $1.5(2.5)$ & \\
\hline More than 9 years & $4.0(2.2)$ & & $0.7(1.8)$ & & $0.7(1.5)$ & \\
\hline \multicolumn{7}{|l|}{ Marital status } \\
\hline With partner & $5.3(2.0)$ & 0.05 & $1.5(2.6)$ & 0.98 & $1.5(2.5)$ & 0.04 \\
\hline Without partner & $4.4(2.5)$ & & $1.0(1.7)$ & & $0.9(2.1)$ & \\
\hline Income & & 0.00 & & 0.29 & & 0.99 \\
\hline$\leq 2$ salaries & $5.2(2.1)$ & & $1.2(2.3)$ & & $1.4(2.5)$ & \\
\hline$>2$ salaries & $3.2(2.5)$ & & $2.0(2.8)$ & & $0.6(0.8)$ & \\
\hline
\end{tabular}

SD: Standard deviation; * Statistical significance $(\mathrm{p}<0.05)$; Mann-Whitney test; Kruskal-Wallis test/ANOVA.

results, the study demonstrated low scores for activities involving foot care. ${ }^{7}$ The study also stressed the statistically significant relationship between the guidelines provided by nurses to patients and self-care of the feet, ${ }^{7}$ demonstrating the effectiveness of promoting self-care by these professionals.

In the international context, an Indian investigation confirmed high scores in activities related to medication use and general diet and low scores related to physical exercise and blood sugar testing. ${ }^{8}$ Consistent with other studies, it demonstrated inadequate foot care behavior. ${ }^{8}$

A recent study, which also estimated the prevalence of self-care practices among diabetic patients, concluded that regular blood sugar testing was the activity with the highest score in contrast to the present data. Furthermore, under 55-year olds showed a better behavior regarding blood sugar testing. ${ }^{9}$

Given this scenario, it is believed that the low means found for blood sugar testing in the present study can be explained by the fact that this sample is mostly constituted by elderly people and probably, also, the participants had type $2 \mathrm{DM}$, rather than type 1 , since this activity was correlated with the duration of insulin use.
Although heterogeneous behaviors are clearly observed in relation to self-care activities, it can be seen that the means of the use of drug therapy are high, both in the current study and in the literature. ${ }^{5,9,17,18}$ Recent research, which identified the most important activities in the control of glycated hemoglobin, suggested that the correct use of medications may be the most important behavior for blood sugar control among adults with diabetes and low socioeconomic status thus demonstrating the importance of reaffirming behavior among diabetics. ${ }^{9,17}$

We can also observe a divergence of data between the present study and the literature regarding attitudes regarding a satisfactory general diet. $6,8,9,19$ The data of this study confirmed a positive association between healthy eating and low income, a situation that is not consistent with the literature, which points to evidence that access to a healthy diet is directly related to socioeconomic conditions. ${ }^{20}$ We also found an inverse but weak correlation of healthy eating with fasting blood glucose, suggesting that adopting an adequate diet may cooperate in metabolic control. 
Table 3. Analysis of associations of nominal sociodemographic variables with self-care activities of the DAQ. São José do Rio Preto, SP, Brazil, 2017.

\begin{tabular}{|c|c|c|c|c|c|c|}
\hline \multirow{2}{*}{$\begin{array}{l}\text { Item } \\
\text { Variable }\end{array}$} & \multicolumn{2}{|c|}{ Check feet } & \multicolumn{2}{|c|}{ Dry between the toes } & \multicolumn{2}{|c|}{$\begin{array}{c}\text { Take indicated number of } \\
\text { tablets }\end{array}$} \\
\hline & Mean (SD) & p* & Mean (SD) & p* & Mean (SD) & $\mathbf{p}^{*}$ \\
\hline Sex & & 0.52 & & 0.16 & & 0.84 \\
\hline Male & $5.2(2.9)$ & & $5.8(2.5)$ & & $6.6(1.5)$ & \\
\hline Female & $5.6(2.9)$ & & $6.4(1.7)$ & & $6.5(1.7)$ & \\
\hline Skin color & & 0.16 & & 0.87 & & 0.14 \\
\hline White & $5.2(2.9)$ & & $6.2(1.9)$ & & $6.8(1.1)$ & \\
\hline Non-white & $5.8(2.4)$ & & $6.1(2.2)$ & & $6.2(2.0)$ & \\
\hline Residence & & 0.09 & & 0.97 & & 0.49 \\
\hline Urban & $5.5(2.6)$ & & $6.1(2.1)$ & & $6.5(1.6)$ & \\
\hline Rural & $3.5(3.8)$ & & $6.6(0.8)$ & & $6.8(0.4)$ & \\
\hline Schooling & & 0.03 & & 0.00 & & 0.52 \\
\hline Illiterate & $4.7(3.1)$ & & $6.0(2.3)$ & & $6.6(1.6)$ & \\
\hline Up to 9 years & $5.7(2.6)$ & & $6.4(1.8)$ & & $6.5(1.7)$ & \\
\hline More than 9 years & $4.2(2.9)$ & & $4.0(3.1)$ & & $7.0(0.0)$ & \\
\hline Marital status & & 0.04 & & 0.57 & & 0.01 \\
\hline With partner & $5.8(2.4)$ & & $6.2(2.0)$ & & $6.7(1.3)$ & \\
\hline Without partner & $4.8(3.0)$ & & $6.0(2.2)$ & & $6.1(2.1)$ & \\
\hline Income & & 0.53 & & 0.88 & & 0.22 \\
\hline$\leq 2$ salaries & $5.5(2.7)$ & & $6.1(2.1)$ & & $6.5(1.7)$ & \\
\hline$>2$ salaries & $5.1(2.9)$ & & $6.4(1.8)$ & & $7.0(0.0)$ & \\
\hline
\end{tabular}

SD: Standard deviation; * Statistical significance $(p<0.05)$; Mann-Whitney test; Kruskal-Wallis test/ANOVA.

Table 4. Analysis of correlations of sociodemographic and clinical variables with self-care activities of the DAQ. São José do Rio Preto, SP, Brazil, 2017.

\begin{tabular}{lccccccccc}
\hline Item & \multicolumn{3}{c}{ General diet } & \multicolumn{2}{c}{$\begin{array}{c}\text { Fruits and veg- } \\
\text { etables }\end{array}$} & \multicolumn{2}{c}{$\begin{array}{c}\text { Red meat/dairy } \\
\text { products }\end{array}$} & \multicolumn{2}{c}{ Physical exercise } \\
Variable & $\mathbf{r}$ & $\mathbf{p ^ { * * }}$ & $\mathbf{r}^{*}$ & $\mathbf{p}^{* *}$ & $\mathbf{r}^{*}$ & $\mathbf{p}^{* *}$ & $\mathbf{r}^{*}$ & $\mathbf{p}^{* *}$ \\
\hline Age & 0.14 & 0.74 & -0.02 & 0.80 & -0.08 & 0.29 & -0.06 & 0.44 \\
\hline Fasting blood glucose & -0.18 & $\mathbf{0 . 0 2}$ & 0.21 & $\mathbf{0 . 0 0}$ & 0.18 & $\mathbf{0 . 0 2}$ & 0.08 & 0.30 \\
\hline Postprandial blood glucose & 0.07 & 0.39 & -0.25 & $\mathbf{0 . 0 0}$ & -0.17 & $\mathbf{0 . 0 3}$ & -0.17 & $\mathbf{0 . 0 3}$ \\
\hline Systolic blood pressure & 0.05 & 0.54 & -0.15 & 0.05 & 0.00 & 0.91 & -0.19 & $\mathbf{0 . 0 1}$ \\
\hline Diastolic blood pressure & 0.04 & 0.56 & 0.12 & 0.12 & 0.08 & 0.33 & -0.05 & 0.48 \\
\hline Body mass index (BMI) & 0.02 & 0.78 & -0.05 & 0.52 & -0.00 & 0.96 & -0.08 & 0.34 \\
\hline Abdominal Circumference & -0.20 & 0.80 & -0.11 & 0.16 & -0.08 & 0.31 & -0.17 & $\mathbf{0 . 0 3}$ \\
\hline Pulse pressure & -0.00 & 0.98 & 0.27 & $\mathbf{0 . 0 0}$ & -0.06 & 0.42 & -0.22 & $\mathbf{0 . 0 0}$ \\
\hline Time since diagnosis & 0.14 & 0.07 & 0.02 & 0.80 & 0.22 & $\mathbf{0 . 0 0}$ & 0.02 & 0.78 \\
\hline Duration of insulin therapy & 0.14 & 0.07 & -0.03 & 0.64 & 0.08 & 0.29 & -0.06 & 0.42 \\
\hline Duration of oral antidiabetic drug use & 0.11 & 0.17 & -0.06 & 0.44 & 0.12 & 0.13 & 0.08 & 0.32 \\
\hline
\end{tabular}

* Statistical value corresponds to the Spearman correlation coefficient; ** Statistical significant $(p<0.05)$. 
Table 5. Analysis of correlations of sociodemographic and clinical variables with self-care activities of the DAQ. São José do Rio Preto, SP, Brazil, 2017.

\begin{tabular}{lcccccc}
\hline Item & \multicolumn{2}{c}{ Blood sugar testing } & \multicolumn{2}{c}{ Check feet } & \multicolumn{2}{c}{ Insulin injections } \\
Variable & $\mathbf{\mathbf { r } ^ { * }}$ & $\mathbf{\mathbf { p } ^ { * * }}$ & $\mathbf{r}^{*}$ & $\mathbf{p}^{* *}$ & $\mathbf{r}^{*}$ & $\mathbf{p}^{* *}$ \\
\hline Age & -0.06 & 0.44 & -0.18 & $\mathbf{0 . 0 2}$ & -0.0 & 0.97 \\
\hline Fasting blood glucose & 0.08 & 0.28 & 0.14 & 0.08 & 0.23 & $\mathbf{0 . 0 0}$ \\
\hline Postprandial blood glucose & 0.06 & 0.45 & -0.04 & 0.59 & -0.08 & 0.32 \\
\hline Systolic blood pressure & $-0,09$ & 0,06 & 0.01 & 0.86 & 0.06 & 0.44 \\
\hline Diastolic blood pressure & $-0,07$ & 0,39 & 0.00 & 0.92 & 0.06 & 0.41 \\
\hline Body mass index (BMI) & -0.04 & 0.55 & 0.08 & 0.31 & 0.13 & 0.10 \\
\hline Abdominal Circumference & -0.12 & 0.13 & 0.04 & 0.56 & 0.09 & 0.27 \\
\hline Pulse pressure & -0.10 & 0.20 & 0.03 & 0.71 & 0.05 & 0.52 \\
\hline Time since diagnosis & 0.05 & 0.49 & 0.09 & 0.26 & 0.05 & 0.51 \\
\hline Duration of insulin therapy & 0.38 & $\mathbf{0 . 0 0}$ & 0.19 & $\mathbf{0 . 0 1}$ & 0.07 & 0.35 \\
\hline Duration of oral antidiabetic drug use & 0.01 & 0.86 & 0.11 & 0.15 & 0.19 & $\mathbf{0 . 0 1}$ \\
\hline
\end{tabular}

* Statistical value corresponds to the Spearman correlation coefficient; ${ }^{* *}$ Statistical significant $(p<0.05)$.

A recent study, conducted with 1,515 diabetics, showed that some type of food control was more prevalent among females. ${ }^{19}$ In light of this evidence, it must be remembered that our sample consisted mostly of females, which may have influenced the high mean found in relation to this activity.

The present sample also showed a low intake of both sweets and fruits and vegetables. Increased consumption of fruits and vegetables was significantly associated with white skin color and residence in rural areas, where it is assumed that access to these foods is facilitated by living close to agriculture.

Research that evaluated the dietary profile before and after the implementation of an educational intervention showed that the increase of healthy food choices, such as high fruit and vegetable intake, was initially associated with a reduction in BMl, lower blood sugar levels and increases in physical exercise.$^{21}$ Confirming the importance of a healthy diet for metabolic control, our findings demonstrated an inverse correlation between postprandial blood sugar and the intake of these foods.

Regarding physical exercising, both in the present study and in the literature, there was a predominance of inappropriate behavior, which reflects the sedentary lifestyle of this population. ${ }^{18,22}$ In a recently published prospective study involving 44,828 Chinese adults with altered glycemic rates, there was an inverse relationship between habitual physical exercise and the risk of developing diabetes. ${ }^{22}$

Another study that analyzed the relationships between adherence to diabetes treatment guidelines and disease-related morbidity and mortality rates showed that adequate adherence to physical exercise recommendations reduced the risk of stroke, renal failure, moderate complications of the lower extremities, lower limb amputation and death. ${ }^{18}$
Nevertheless, this study demonstrated an inverse correlation of physical exercise with postprandial blood glucose levels, SBP, PP and abdominal circumference values, corroborating the evidence that the satisfactory behavior related to this activity contributes directly and indirectly to metabolic control and to reducing cardiovascular risk.

Regarding adherence to foot care, divergences were also found between the studies consulted and the current findings. ${ }^{6,8,19}$ Recent data have shown that men present greater deficits compared to women with regard to prevention of diabetic foot. ${ }^{19}$ Again, it should be stressed here that the present sample was predominantly female, a fact that may have contributed to the high mean, that is favorable behavior, related to foot care.

A large Brazilian study involving 1,455 people demonstrated that independent risk factors for ulcers included male gender, smoking, neuroischemic foot classification, presence of retinopathy and absent vibratory sensation. ${ }^{23}$ The risk factors for amputation were, among others, male gender, type 2 DM and previous history of ulcers. ${ }^{23}$ Faced with the knowledge of this range of risk factors, the essential role of simple self-care activities such as daily and routine foot examinations and drying between the toes after bathing to prevent and detect early plantar ulcers is clear.

Regarding the association of clinical and sociodemographic variables, it is important to point out that the condition that influenced the greatest number of self-care activities was the marital status, since the presence of a partner was positively associated with satisfactory behaviors in regards to regular blood sugar testing, foot examinations and drug therapy.

Consistent with these data, recent evidence has demonstrated the positive representations of partners about self-care 
behavior in newly diagnosed patients with type $2 \mathrm{DM} .{ }^{24}$ It is believed that the presence of a partner enhances positive attitudes towards care of one's own health, and the patient/companion dyad should be considered in therapeutic planning.

The limitations of this study are related to the cross-sectional research design, which does not make it possible to verify the cause-effect relationships between the variables over time. Identifying which behaviors are the most important for controlling metabolic values among diabetic patients would be particularly useful in policy and intervention measures for this high-risk group. In addition, the non-probabilistic sampling type is also an important limitation.

\section{CONCLUSION}

Of the 15 self-care activities evaluated, the activity that obtained the highest score corresponds to the use of drug therapy, and the lowest scores were for fruit and vegetable consumption, blood sugar testing and physical exercise. There were significant correlations of skin color and place of residence with consumption of fruits and vegetables; income with general diet; marital status with blood sugar testing; schooling and marital status with foot care; and of marital status with taking the indicated number of pills. There was also a correlation of postprandial glycemia with fruit and vegetable intake; postprandial blood glucose, SBP, abdominal circumference, and PP with physical exercise; fasting blood glucose with general diet; age with examination of the feet; and blood sugar testing with duration of insulin therapy.

The results of this research contribute to strengthening the line of care in chronic diseases and assist by stressing the importance of supported self-care. Nurses need to develop and incorporate skills in developing knowledge about self-care and defend their formal integration in the delivery of health care.

\section{REFERENCES}

1. Kozakova M, Palombo C. Diabetes Mellitus, Arterial Wall, and Cardiovascular Risk Assessment. Int J Environ Res Public Health [Internet]. 2016 Feb; [cited 2017 Jul 13]; 13(2):201. Available from: https://www.ncbi.nlm.nih.gov/pubmed/26861377

2. Mahmoudzadeh-Zarandi F, Hamedanizadeh F, Ebadi A, Raiesifar A. The effectiveness of Orem's self-care program on headache-related disability in migraine patients. Iran J Neurol [Internet]. 2016 Oct; [cited 2017 Jul 13]; 15(4):240-7. Available from: https://www.ncbi.nlm.nih. gov/pubmed/28435636

3. Ferdinand KC, Senatore FF, Clayton-Jeter H, Cryer DR, Lewin JC, Nasser AS, et al. Improving Medication Adherence in Cardiometabolic Disease: Practical and Regulatory Implications. J Am Coll Cardiol [Internet]. 2017 Jan; [cited 2017 Jul 13]; 69(4):437-51. Available from: https://www.ncbi.nlm.nih.gov/pubmed/28126162

4. American Diabetes Association. Standards of medical care in diabetes-2017. Diabetes care [Internet]. 2017; [cited 2017 Jul 13]; 40(Suppl. 1):S1-2. Available from: http://care.diabetesjournals.org/ content/diacare/suppl/2016/12/15/40.Supplement_1.DC1/DC_40_ S1_final.pdf
5. Souza JD, Baptista MHB, Gomides DS, Pace AE. Adesão ao cuidado em diabetes mellitus nos três níveis de atenção à saúde. Esc Anna Nery [Internet]. 2017 Oct; [cited 2018 Apr 3]; 21(4):e20170045. Available from: http://www.scielo.br/scielo.php?script=sci_arttext\&pid=S141481452017000400232\&lng=pt\&nrm=iso\&tlng=pt

6. Coelho ACM, Villas Boas LCG, Gomides DS, Foss-Freitas MC, Pace AE. Atividades de autocuidado e suas relações com controle metabólico e clínico das pessoas com diabetes mellitus. Texto Contexto Enferm [Internet]. 2015 Jul/Sep; [cited 2018 Jan 5]; 24(3):697-705. Available from: http://www.scielo.br/scielo.php?script=sci_arttext\&pid=S010407072015000300697\&lng=en\&tlng=en

7. Rezende Neta DS, Silva ARV, Silva GRF. Adesão das pessoas com diabetes mellitus ao autocuidado com os pés. Rev Bras Enferm [Internet] 2015; [cited 2018 Apr 3]; 68(1):111-6. Available from: http://www. scielo.br/scielo.php?pid=S0034-71672015000100111\&script=sci abstract\&tlng=pt

8. Srinath KM, Basavegowda M, Tharuni NS. Diabetic self care practices in rural Mysuru, Southern Karnataka, India - A need for Diabetes Self Management Educational (DSME) program. Diabetes Metab Syndr [Internet]. 2017 Nov; [cited 2018 Jan 5]; 11(Suppl 1):S181-6. Available from: https://www.ncbi.nlm.nih.gov/pubmed/28089167

9. Kimando MW, Otieno FCF, Ogola EN, Mutai K. Adequacy of control of cardiovascular risk factors in ambulatory patients with type 2 diabetes attending diabetes out-patients clinic at a county hospital, Kenya. BMC Endocr Disord [Internet]. 2017 Dec; [cited 2018 Jan 5]; 17(1):73. Available from: https://www.ncbi.nlm.nih.gov/pubmed/29191193

10. Chrvala CA, Sherr D, Lipman RD. Diabetes self-management education for adults with type diabetes mellitus: A systematic review of the effect on glycemic control. Patient Educ Couns [Internet]. 2016 Jun; [cited 2017 Jul 13]; 99(6):926-43. Available from: https://www.ncbi.nlm.nih. gov/pubmed/26658704

11. Kueh YC, Morris $T$, Ismail AA. The effect of diabetes knowledge and attitudes on self-management and quality of life among people with type 2 diabetes. Psychol Health Med [Internet]. 2017 Feb; [cited 2017 Jul 13]; 22(2):138-44. Available from: https://www.ncbi.nlm.nih.gov/ pubmed/26851120

12. Cavicchioli MG, Guerbali CC, Ochiai C, Silva RM, Camara G, Petry TB The Contribution of Diabetes Education in the Treatment of People with Type 2 Diabetes and Risk of Cardiovascular Disease. Curr Atheroscler Rep [Internet]. 2016 Jul; [cited 2017 Nov 15]; 18(7):44. Available from: https://www.ncbi.nlm.nih.gov/pubmed/27260145

13. Malachias MVB, Souza WKSB, Plavnik FL, Rodrigues CIS, Brandão AA, Neves MFT, et al. $7^{\text {a }}$ Diretriz Brasileira de Hipertensão Arterial. Arq Bras Cardiol [Internet]. 2016; [cited 2017 nov 15]; 107(3 Supl 3):1-103. Available from: http://publicacoes.cardiol.br/2014/diretrizes/2016/05_ HIPERTENSAO_ARTERIAL.pdf

14. Associação Brasileira para o Estudo da Obesidade e da Síndrome Metabólica. Diretrizes brasileiras de obesidade 2016/ABESO - Associação Brasileira para o Estudo da Obesidade e da Síndrome Metabólica. 4a ed. São Paulo; 2016 [Internet]. [cited 2017 Nov 15]. Available from: http://www.abeso.org.br/uploads/ downloads/92/57fccc403e5da.pdf

15. Michels MJ, Coral MHCC, Sakae TM, Damas TB, Furlanetto LM Questionário de Atividades de Autocuidado com o Diabetes: tradução, adaptação e avaliação das propriedades psicométricas. Arq Bras Endocrinol Metab [Internet]. 2010 Oct; [cited 2017 Nov 15]; 54(7):64451. Available from: http://www.scielo.br/scielo.php?script=sci_arttext\& pid=S0004-27302010000700009

16. Toobert DJ, Hampson SE, Glasgow RE. The summary of diabetes self-care activities measure: results from 7 studies and a revised scale. Diabetes Care [Internet]. 2000 Jul; [cited 2017 Nov 15]; 23(7):943-50. Available from: https://www.ncbi.nlm.nih.gov/pubmed/10895844

17. Osborn CY, Mayberry LS, Kim JM. Medication adherence may be more important than other behaviours for optimizing glycaemic contro among low-income adults. J Clin Pharm Ther [Internet]. 2016 Jun; [cited 2018 Jan 5]; 41(3):256-9. Available from: https://www.ncbi.nlm.nih.gov/ pubmed/26939721 
18. Chen Y, Sloan FA, Yashkin AP. Adherence to diabetes guidelines for screening, physical activity and medication and onset of complications and death. J Diabetes Complications [Internet]. 2015 Dec; [cited 2018 Jan 5]; 29(8):1228-33. Available from: https://www.ncbi.nlm.nih.gov/ pubmed/26316423

19. Rossaneis MA, Haddad Mdo C, Mathias TA, Marcon SS. Differences in foot self-care and lifestyle between men and women with diabetes mellitus. Rev Lat Am Enferm [Internet]. 2016 Aug; [cited 2018 Jan 5]; 24:e2761. Available from: https://www.ncbi.nlm.nih.gov/ pubmed/27533270

20. Vasconcelos SML, Torres NCP, Silva PMC, Santos TMP, Silva JVL, Omena CMB, et al. Insegurança Alimentar em Domicílios de Indivíduos Portadores de Hipertensão e/ou Diabetes. Int J Cardiovasc Sci [Internet] 2015; [cited 2017 May 5]; 28(2):114-21. Available from: http://www. onlineijcs.org/sumario/28/pdf/v28n2a06.pdf

21. Teufel-Shone NI, Jiang L, Beals J, Henderson WG, Acton KJ, Roubideaux $Y$, et al. Changes in Food Choices of Participants in the Special Diabetes Program for Indians-Diabetes Prevention Demonstration Project, 20062010. Prev Chronic Dis [Internet]. 2015 Nov; [cited 2018 Jan 5]; 12:E193. Available from: https://www.ncbi.nlm.nih.gov/pubmed/26564009
22. Lao XQ, Deng HB, Liu X, Chan TC, Zhang Z, Chang LY, et al. Increased leisure-time physical activity associated with lower onset of diabetes in 44828 adults with impaired fasting glucose: a population-based prospective cohort study. Br J Sports Med [Internet]. 2018 Jan 13; [cited 2018 Jan 5]; pii: bjsports-2017-098199. [Epub ahead of print]. Available from: https://www.ncbi.nlm.nih.gov/pubmed/29331993

23. Parisi MC, Moura Neto A, Menezes FH, Gomes MB, Teixeira RM, Oliveira JE, et al. Baseline characteristics and risk factors for ulcer, amputation and severe neuropathy in diabetic foot at risk: the BRAZUPA study. Diabetol Metab Syndr [Internet]. 2016 Mar; [cited 2018 Jan 5]; 8(25). Available from: https://www.ncbi.nlm.nih.gov/pmc/articles/ PMC4794830/

24. Pereira MG, Pedras S, Machado JC, Ferreira G. Partners' representations of diabetes as mediators between patients' representations and adherence to self-care behaviors, in type 2 diabetes. Psychol Health Med [Internet]. 2016 Sep; [cited 2018 Jan 5]; 21(6):707-14. Available from: https://www.ncbi.nlm.nih.gov/pubmed/26718034 